\title{
13 "Wagnerism": responses to Wagner in music and the arts
}

\author{
ANNEGRET FAUSER
}

Wagner's impact on Western culture can hardly be overestimated. When Howard Shore describes his use of leitmotifs in the Oscar-winning score for the blockbuster trilogy The Lord of the Rings (2001-03), for example, he reveals himself as but one recent musician in a long line of creative artists affected by Wagner the composer. ${ }^{1}$ Wagner's theories about musical theater can be felt even in contemporary discussions of Broadway musicals, such as Oklahoma! (1943) and Rent (1996). ${ }^{2}$ As for modern opera, Olivier Messiaen's Saint François d'Assise (1983), Luciano Berio's Un re in ascolto (1984), and Karlheinz Stockhausen's cycle Licht (1977-2004) are among the more recent responses to the challenges posed by Wagner almost 150 years ago. In fact, artists from all disciplines over the last century and a half have likewise relied on aesthetic concepts shaped prominently by Wagnerian ideas about the nature of art, whether Symbolist poets such as Charles Baudelaire, Paul Verlaine, and Stéphane Mallarmé; avant-garde painters such as Wassily Kandinsky, Pablo Picasso, Joseph Beuys, and Anselm Kiefer; the sculptors Hans Arp and Auguste Rodin; or the architects of the Bauhaus. Media technology itself, when related to art, has drawn its aesthetic justification from Wagner's thoughts. ${ }^{3}$ And his political and social views influenced the Zionist Theodor Herzl as well as the anti-Semitic fascist Adolph Hitler, with repercussions still powerfully felt in concert life today - in Israel, above all, but worldwide as well. This expansive and often cult-like reception phenomenon is usually designated by the term "Wagnerism" - one of the few isms associated with the name of an individual composer. Indeed the term became quickly associated with an ideologically tinted reception of Wagner's music and writings as an all-encompassing theoretical system, whose partisan followers invoked the perceived teachings of the master rather as Marxists invoke those of that famous German contemporary.

Any discussion of Wagnerism, however, needs to distinguish between specifically compositional and musical-aesthetic responses to Wagner's oeuvre, on the one hand, and more general literary, artistic, and political reactions to his music and writings, on the other. In contrast to writers and painters, of course, composers had to engage with Wagner in his primary medium - that of sound. This created very different anxieties, challenges, and 
opportunities, and it demanded strategies for the engagement with Wagner other than those adopted by non-musicians. As musical Wagnerism spread through Europe and the United States, composers and critics tried to rhake use of (or resist) Wagnerian approaches while avoiding direct imitation. Writers, painters, sculptors, and architects, however, had the freedom to use Wagnerian ideas without threatening their originality. But both groups were fascinated by Wagner's new emphasis on the materiality of art, by his analysis of its constituent elements, and by his demand for their synthesis in some newly integrated, "total" artwork. Wagner thus opened the way to modernism with its ever increasing focus on the manipulation and meaning of the artistic medium itself.

\section{Musical responses to Wagner}

For composers, Wagner offered both challenges and promises. His theoretical writings claimed a new role for the musician-poet as a possible redeemer of modern society, while his music employed textural and sonic means that would influence compositional techniques not only in opera but also in symphony, symphonic poem, and song. Intertwined with these musical and aesthetic frameworks was the strong element of musical nationalism in Wagner's works and writings as well as in their musical and critical reception. Eventually, the very phenomenon of musical Wagnerism called forth a whole new pattern of negative responses, mainly in the earlier twentieth century, in an effort to get out from under the composer's suffocating influence.

Wagner's musical language was perceived as offering two important new pathways for composers. On the one hand, it contained such fascinating musical elements as expanded chromatic harmony, quasi-polyphonic voice leading, the dramaturgical use of orchestral timbre, and idiosyncratic combinations of instruments. On the other, Wagner offered fresh approaches to musical organization with his leitmotifs, his endless melody (related to Arnold Schoenberg's concept of "musical prose"), and his rebalancing of musical texture, especially in the relation of voice and orchestra. While many of these elements, even the so-called Tristan chord (F-B-D\#-G\#; perhaps his most famous harmonic signature), can also be traced to predecessors and contemporaries of Wagner, it was his use of them within a cohesive compositional and aesthetic framework that led to a near-universal Wagnerian influence on European music at the end of the nineteenth century.

The musical reception of Wagner might best be viewed in different lights depending on whether one is considering specific works (teasing out the separate strands defining the reception of, say, Tannhäuser and Lohengrin, on the one hand, or the Ring and the remaining music dramas, 
on the other), his musical output as a whole, or even just his theories of music drama. Broadly speaking, however, composers engaged with Wagner's musical language essentially in two different ways. Musicians such as Camille Saint-Saëns, Giacomo Puccini, or Nikolai Rimsky-Korsakov mined this language for those elements that could be incorporated into their own musical fabric just as they would appropriate elements of Beethoven, Verdi, or Gounod. Others, like Ernest Chausson, Henri Duparc, Augusta Holmès, Hugo Wolf, or Anton Bruckner tried to engage with the totality of Wagner's work and theories either to follow in his footsteps as composers of a new kind of opera ("music drama"), or to develop these Wagnerian impulses in other genres (the art song or the symphony).

Given Wagner's own compositional output and aesthetic hierarchies, music drama became the prime genre for composers to engage with Wagnerian models. Particularly in France, where opera had been regarded as a reflection of the "nation's image" since the founding of the Académie Royale de Musique under Louis XIV, the musical and dramatic challenges posed by Wagner became central to his reception as both a threat to, and potential savior of, this central genre. ${ }^{4}$ In the first half of the nineteenth century, Paris had become not only the "capital of the nineteenth century," as Walter Benjamin famously put it but, more particularly, the center of European opera: French grand opera set the international standard for the genre, and the most important European venue even for Italian opera especially between the 1820 s and 1850s - was arguably the Parisian Théâtre Italien. Moreover, Franco-German relations were famously problematic throughout the nineteenth century, and Wagner's own love-hate relationship with Paris was fully reciprocated in both directions. Hence the irony that the first wave of musical Wagnerism was located within French opera. After discussions of Wagner's so-called system of composition from 1852 onward in journals such as the Revue et Gazette Musicale de Paris, and especially following the Tannhäuser scandal of 1861, Wagner became an unavoidable and controversial figure of reference, whether in critical discourse or compositional appropriation. ${ }^{5}$

We might identify three forms of Wagner reception in French musical theater: literary references, musical appropriations, and the notion of the "musician-poet." At first, Wagner's influence prompted a shift of opera plots from the traditional historical subjects of grands opéras such as Rossini's Guillaume Tell (1829), Meyerbeer's Les Huguenots (1836), or Verdi's Vêpres siciliennes (1855) - denounced by Wagner as distracting the audience through faits divers (assorted historical "headlines," so to speak) - to the realm of medieval legends, more apt for the presentation of eternal truths, in Wagner's view. Ernest Reyer's Sigurd (1884) - first conceived in the 1860s and based on a French translation of the Nibelungenlied - and Hector 
Berlioz's Les Troyens (1863), which set the Latin (and by extension thus French) legend of the Aeneid, counted as Wagnerian operas, even though their musical organization was strongly rooted in the forms of grand ipéra. French medieval legends became the literary sources of self-conscious choice in Wagnerian works of the 1880s and 1890s, as, for example, in Edouard Lalo's Le roi d'Ys (1888), Vincent d'Indy's Fervaal (1897), Claude Debussy's Pelléas et Mélisande (1902), and Ernest Chausson's Le Roi Arthus (1903). In this way, Wagner's influence could be melded with more inherently nationalist concerns, especially important after the French defeat in the Franco-Prussian war of 1870-71. The Wagnerian traits of Jules Massenet's Esclarmonde - premiered in May 1889 during the World's Fair as the Parisian opera to showcase French achievement on the musical stage were avidly discussed by the Parisian press. ${ }^{6}$ Journalists tried to show their philological erudition by exploring the medieval literary sources in great detail, assessing the literary pedigree of this French opera in contrast to Wagner's own uses of medieval literature. ${ }^{7}$ Once Wagnerian rhetoric had established legendary epic as a source for operatic subjects, the trend could be emblematic even as it mutated. Thus, Gustave Charpentier's use of an urban "legend" - that of Montmartre - for his opera Louise (1900) might be viewed as much in the spirit of Wagnerism as the continued recourse to medievalism in works such as Lili Boulanger's unfinished La Princesse Maleine (1916-18).

Wagnerian influence extended far beyond mere subject matter. Massenet, Reyer, and Saint-Saëns tried to find a path that would integrate the selfconsciously "French" compositional style of earlier grand opéra with Wagnerian elements of orchestration, motivic organization, and chromatic harmony. How self-conscious composers were about these choices can be seen in the score of Esclarmonde, where Massenet cites the Tristan chord when Esclarmonde's sister asks about her love interest in the hero Roland ("But you think of him?"). ${ }^{8}$ The musical pun - itself very Wagnerian, if one recalls that composer's self-quotation of Tristan und Isolde in the last act of Die Meistersinger - shows a high degree of self-reflexivity on the part of Massenet and his contemporaries when engaging with the sound-world of Wagner.

While these composers seem to have striven for the "happy medium" so characteristic of French aesthetics of the nineteenth century, others chose a far more difficult route of engagement. Taking on the entire "system" of music drama, Chabrier, Chausson, d'Indy, Holmès, and Debussy all tried to find their voices in the shadow of the German giant. Their letters reveal how difficult this was. Chausson wrote to Raymond Bonheur in the course of working on his Arthurian music drama, Le Roi Arthus: "Wagner, whom I no longer feel weighing on me when I write symphonic music, now haunts 
me terribly. I flee him as much as I can, but flee all I want, he is always here, near me, waiting for me very spitefully and making me write piles of things that I erase. I am very annoyed about this. I have to escape this devil of a man, however. It is a question of life or death." Some months later, Debussy announced to Chausson that he had destroyed a scene from Pelléas because he discovered "the ghost of old Klingsor, alias R. Wagner," in some of its newly composed music. ${ }^{10}$ At stake for these composers was success or failure in the nationalist enterprise of creating the modern French masterwork, building on Wagner yet transcending him at the same time. ${ }^{11}$ While Massenet could quote the Tristan chord as a kind of musical joke in Esclarmonde, Chausson and Debussy had to fight for artistic survival because their musical grammar and vocabulary was initially so dangerously close to Wagner's. And while later music historians have often tried to show the differences between those French composers and their model, the musicians themselves - who sought to achieve musico-dramatic organicism through Wagnerian uses of leitmotif, orchestration, and form - were deeply aware of the anxieties created by so strong an influence. Debussy's own quotations of Tristan in his Prélude à l'après-midi d'un faune, Pelléas et Mélisande, and even the satirical Golliwogg's Cakewalk are far more anxious, it seems, than Massenet's.

Wagner's impact on French opera was also evident in attitudes toward the libretto. No longer satisfied by the formal and stylized language of an Eugène Scribe or Michel Carré, many musicians looked for a different literary quality in playwrights such as Maurice Maeterlinck or Auguste Villiers de l'Isle Adam - a trend that would lead to the twentieth-century phenomenon of Literaturoper, that is, the setting of prose plays as operas. (Debussy's Pelléas et Mélisande, Richard Strauss's Salome, and Alban Berg's Wozzeck are prime examples.) Another trend adopted particularly in France was the notion of the musician-poet: Charpentier, Chausson, d'Indy, and Albéric Magnard all wrote their own librettos, as did, notably, a significant number of women composers. While this was originally born of necessity (access to professional librettists was scarce), female opera composers Célanie Carissan, Marie Clémence Vicomtesse de Grandval, Holmès, Marguerite Olagnier, Rita Strohl, and Pauline Thys could now point to the example of Wagner and his male disciples for validation of a practice that might otherwise be perceived as amateurish. ${ }^{12}$ Indeed, in a review of Holmès's 1889 Ode triomphale, the critic praised her as the one French musician-poet worthy of Homer and Wagner, showing how widely this concept had penetrated French critical discourse. ${ }^{13}$

The French preoccupation with Wagner as the colossus looming over the operatic production of the later nineteenth and early twentieth centuries was increasingly shared by other European musical cultures. Especially in 
Italy - a nation proud of its native operatic tradition - Wagner became an irritant. The Lohengrin craze in Bologna in the 1870s (following the first production of a Wagner opera in Italy) was something of an exception, and it stood in stark contrast with the wariness other leading operatic centers, such as Milan or Turin, exhibited toward the German composer. ${ }^{14}$ But like French composers - and mediated through them - Italian composers started to engage with Wagnerian music and aesthetics. In the wake of efforts of the progressive poetic faction known as the Scapigliatura (including Verdi's later collaborator, Arrigo Boito) to forge a modern Italian literature, writers such as Ferdinando Fontana, with his tract In teatro (1884), found in Wagner a guiding spirit in the search for a renewed and modern musical theater. Composers responded to the challenge with alacrity. Like Massenet, Giacomo Puccini appropriated Wagnerian techniques, such as the use of leitmotifs, the dramaturgical use of orchestration, and declamatory musical prose, while retaining some of the formal structures of older opera. Prime examples for this approach are his La Bohème (1896) and Tosca (1900). ${ }^{15}$ Indeed, both are through-composed and tightly organized through leitmotifs and timbral dramaturgy, while incorporating at least vestiges of traditional Italian arias and ensembles, as in Tosca's "Vissi d'arte" or Rodolfo's "Che gelida manina." Conceived as an Italian countercycle to Wagner's Ring, the musician-poet Ruggero Leoncavallo's project of a "Poema epico in forma di Trilogia Storica" was meant to bring the glory of Italy's past on the fin de siecle stage. Only the first opera of the trilogy, I Medici (1893), was ever finished - and Leoncavallo made his musical engagement with Wagner audible from the first moment with a quotation of the well-known Venusberg scene from Tannhäuser. ${ }^{16}$

Both Italy and France had faced in Wagner a powerful foreign figure who had publicly slandered their proud operatic traditions in print. In Germany itself, Wagner was a central participant in the musical development of the slowly forming nation, chastising fellow German musicians for their lack of vision. He became involved in controversies (the New German School, for example) whose focus was not necessarily opera, but instrumental music. Nevertheless, composers sympathetic to Wagnerian ideals - such as Peter Cornelius and Engelbert Humperdinck - found it almost impossible to escape the shadow of Wagner, as, for example, in Cornelius's Der Cid (1865) or Humperdinck's Hänsel und Gretel (1893). ${ }^{17}$ But for them, and even for Hugo Wolf, comic opera provided a space relatively unthreatened by Wagnerism. They followed instead the successful traditions of Albert Lortzing and Friedrich von Flotow, whereas Wagner's Die Meistersinger von Nümberg was, in any case, rarely viewed as a comic opera in the traditional sense. A later German attempt at a Wagnerian operatic cycle in August Bungert's Homerische Welt (1898-1903) remained marginal to 
German music history. ${ }^{18}$ It was not until Richard Strauss that a major German composer successfully confronted the Wagnerian challenges to music drama head-on. After the failure of the overtly Wagnerian music drama Guntram (1894) and the succès de scandale of the ribald one-act comedy Feuersnot (1901), Strauss found his voice as a post-Wagnerian opera composer in Salome (1905) and Elektra (1909). Both works count as key examples of Literaturoper, and Strauss's setting pushed the envelope of Wagnerian music in terms of through-composed prose setting, chromatic harmony, and orchestration.

Wagner reception in opera elsewhere in Europe and in the United States can be traced mainly through the recourse to medieval legends or other patriotic subjects associated with specific nation-building. Thus, in Finland, for example, Jean Sibelius began work on an opera based on legends from the national epic Kalevala, while in Russia Rimsky-Korsakov composed Mlada (1892), a music drama whose plot stemmed from the mythology of the Baltic Slavs, with overtones of the Norse mythology of Wagner's Ring. ${ }^{19}$ Composers in other countries looked at medieval plots - for example, the Hungarian Ferenc Erkel in Bánk bán (1861) - folk legends, and fairy tales. In musical terms, the influence of Wagnerian music drama often remained limited to the use of leitmotifs, orchestral effects, and Wagnerian musical allusions within more traditional operatic forms, these remaining in the vein of either French grand opéra, middle Verdi, or the Wagner of Rienzi and the "Romantic" operas through Lohengrin.

While the operatic stage formed the center of musical Wagner reception, instrumental music became nevertheless an important locus of engagement with the composer. The symphony stood in need of a new legitimization in post-Wagnerian aesthetics after the infamous declaration in Das Kunstwerk der Zukunft (The Artwork of the Future; 1849) that the genre had died with Beethoven's Ninth Symphony. Wagner's attack needs to be seen in the context of the aesthetic debates in Germany in the middle of the nineteenth century, where symphonic music was celebrated as the acme of national musical accomplishment in a highly competitive European environment, whereas France and Italy maintained primacy in opera. $^{20}$ In order to wrest the claim to superiority from his operatic European neighbors as well as his German symphonic colleagues, Wagner identified music drama as the genre that not only fulfilled the potential of opera in its widest definition but also superseded the symphony in representing the highest of human aspirations in idealized form. ${ }^{21}$ In response to these challenges, symphonic composers such as Anton Bruckner and Gustav Mahler in Austria tried to reconcile the ideologies of post-Wagnerian modernism as a cult of rupture, progress, sonic expansion, and the "artwork of ideas" with the aesthetic and formal demands 
of the post-Beethovenian symphony. ${ }^{22}$ When Mahler wrote that symphony meant to him "constructing a world with all the resources of the available techniques," he transformed the rhetoric of the Wagnerian Gesamtkunstwerk into the realm of symphonic music. ${ }^{23}$ The full spectrum of sonorities - from the apparently trivial sounds of pastoral cowbells in his sixth symphony to the massed choir and orchestra of the "Symphony of a Thousand" (No. 8) - was thus available to the composer to convey his Weltanschauung through the hallowed genre of the symphony, in which "in fact the whole world is mirrored. ${ }^{m 24}$ The cyclic thematic structure associated with Beethoven was reinterpreted through the lens of Wagnerian leitmotivic organization in this reinvented symphonic genre of the fin de siècle; the chromatic harmony and rich orchestration associated, especially, with the sonic world of Tristan and Parsifal, could be employed as signifiers of musical modernity in works whose ever increasing length and scope created an ideological and musical mirror to Wagnerian music drama in the increasingly sacralized ritual of bourgeois concert life.

In France, this trend started with César Franck, whose D-minor Symphony (1888) not only paid homage to Beethoven's Ninth but explored Wagnerian (and Lisztian) techniques in its musical organization and language. Franck's pupils, especially Chausson and d'Indy, pushed this trend further, while simultaneously engaging in a nationalist rhetoric that pitted the French modernist development of the symphony against the alleged weaknesses of Johannes Brahms or the likes of Joachim Raff. Edouard Lalo's criticism of Brahms as symphonic composer is typical for this polemic, wherein he described the Second Symphony as a badly orchestrated piece of chamber music. ${ }^{25}$ This ideological view of the symphony as an alternative to music drama, embodying messages of eternal truth, became seductive given that, with the shift from opera to instrumental music, it was less fraught with anxieties of influence. Hybrid works such as Mahler's Das Lied von der Erde (1909) and Schoenberg's Gurrelieder (1911) would push the boundaries of the Wagnerian symphony even further, as did the opulent synesthesia of Alexander Scriabin's Poème de l'extase (1905-08).

Musical Wagnerism also found its way into chamber music. Best known among these works is Schoenberg's string sextet Verklärte Nacht, op. 4 (1899), which might almost be read as an early modernist "cover" of Wagner's Parsifal, reversing the redemptive self-sacrifice of Kundry in life-affirming celebration of sexual ecstasy and human worldliness. ${ }^{26}$ Schoenberg's chamber-musical Gesamtkunstwerk relies on a sophisticated listener's memory of the world of Parsifal (still only performed in Bayreuth at this time, but available as a score) and on her experience with nineteenthcentury program music to decode the musical narrative. ${ }^{27}$ Schoenberg's use 
of leitmotif, his expansion of Wagnerian chromaticism by pushing quasipolyphonic voice-leading to extremes, and his references to Parsifal (in particular the quotation of "Kundry's laughter" in mm. 137-40 and the optimistic D-major ending of the work) create an intertextual engagement with Wagner that surely was not lost on his Viennese audience.

Not only instrumental music but also song provided a field for composers to engage with Wagner. Especially in France, song - whether accompanied by piano, ensemble, or orchestra - played with chromatic harmony and voice-leading in Wagnerian ways. Characteristic examples are such exquisite miniatures as Henri Duparc's Phidylé and Invitation au voyage, Gabriel Fauré's settings of Paul Verlaine, especially La bonne chanson, and Boulanger's Clairières dans le ciel. Indeed, the sixth song in Boulanger's cycle, "Dans l'immense tristesse," is built entirely on an ostinato motive drawn from the opening of Tristan. In Germany, Hugo Wolfs oeuvre reflects a new Wagnerian aesthetics of song composition, as do the song cycles by Mahler and Richard Strauss, while in Britain such composers as Amelia Woodeforde-Finden - especially in her "Kashmiri Song" from the Four Indian Love Lyrics from "The Garden of Kama" (1903) - draw on Wagner's chromatic harmony to infuse the Orientalist settings with sensuously modern sonorities. The song-cycle, however, that pushed the postWagnerian emancipation of dissonance and musical prose, as expressive means, to their limits was Schoenberg's Buch der hängenden Gärten (1908). When Richard Strauss, in his Four Last Songs (1948), had late recourse to Wagnerian sounds and textures, those formerly modernist sonorities had turned into self-conscious signifiers of musical nostalgia for that epoch of "Wagnerism" that was now long past.

\section{Extra-musical Wagnerism}

Fascinated by Wagnerian reflections on the materiality and interdependence of the arts in his theoretical writings, writers and visual artists also used Wagnerian notions of the Gesamtkunstwerk as a catalyst to explore their own methods of artistic production. Thus, the artistic medium (whether language or painting) was no longer transparent in the act of representation, but became itself an object of creative exploration. But if the self-conscious reflection on artistic materiality was one aspect of Wagnerism in the arts, a second strain can be found in more specific subject matters associated with Wagner: not only operas, but also plays inspired by Wagner delved into the abstraction of legends, pushing them further toward the investigation of the human psyche in all its facets, whether in the theater of the decadent movement (Oscar Wilde's Salome 
or Villiers de l'Isle-Adam's Axel) or in symbolist paintings (Odilon Redon, Gustave Moreau, or the English pre-Raphaelites).

Again, France acted as a prism for the development of Wagnerism in its broader sense, with poetry and literary criticism leading the avantgarde. From the late 1850 s onwards, poets and writers picked up on the strange sonorities of Wagner's librettos, which Charles Nuitter, Alfred Ernst, and Victor Wilder had tried to render in French in such a way that the translations reflected the idiosyncrasies of Wagner's alliterative Stabreim. ${ }^{28}$ In contrast to earlier conventions of libretto translation, where the foreign language was rendered in idiomatic French, these translations tried to capture what was specifically Wagnerian in the original German even to the detriment of comprehension in French. The syntax, sonorities, and often hermetic structure of Symbolist poetry by Baudelaire, Verlaine, and Mallarmé can thus be traced back to the order and choice of words in these translations. Prepared by reading the libretti and Wagner's theories about art (in particular his "Lettre sur la musique," published in Paris in 1860 and subsequently in German as "Zukunftsmusik"), poets such as Baudelaire opened themselves up to the experience of the performance of Wagner's music as a sonic revelation of artistic truth. Baudelaire's famous Tannhäuser essay and, later on, Mallarmé's equally influential "Richard Wagner: rêverie d'un poète français" (1885) became signal texts in the aesthetic foundation of French Symbolism. Wagnerian concepts such as the leitmotif and "wordtone melody" found their equivalent in the Symbolist poetics of "correspondence" - explored lyrically in Baudelaire's poem "Correspondances" from Les Fleurs du mal (1857), and in a more explicit form in Arthur Rimbaud's famous "Délires II" from Une saison en Enfer (1873), where he assigned specific colors (red, blue, green) to corresponding vowels:

I have invented the color of vowels! - $A$ black, $E$ white, I red, O blue, $U$ green. - I have decided upon the form and the movement of each consonant and, with instinctive rhythms, I have flattered myself to have invented a poetic word accessible, one day, to all senses. I reserved the translation for myself. ${ }^{29}$

Other poets took up the system of correspondence, in particular René Ghil who related instrumental timbres, colors, emotions, and letters in his Traité du verbe (1885), while Mallarmé claimed that his poetry was, in fact, music. $^{30}$

By exploring the medium of poetic language and its "sonic" materiality, its ability to become expressive merely as sound, conflating signifier and signified, poets tried to forge an artistic tool that could express what was beyond the one-dimensional prose of words and reach what was deemed to be the "inexpressible." This poetic Wagnerism of the French Symbolists and Decadents was picked up in the 1880s and 1890s by the 
literary avant-garde of Europe and became melded with Freudian psychology (which itself had strong Wagnerist undertones, for example, in its reference to figures and archetypes of myth). This is reflected in the works of such diverse authors, and of diverse nationalities, as Richard Dehmel, Peter Altenberg, Stefan George, August Strindberg, Henrik Ibsen, Oscar Wilde, Gabriele d'Annunzio, and Hugo von Hofmannsthal. Even after World War I, neither Gertrude Stein's famous challenge to Symbolist complexity ("A rose is a rose is a rose") nor James Joyce's literary Gesamtkunstwerk, Ulysses, could have been written without the influence of European Wagnerism. Indeed, during the later nineteenth century and in the early decades of the twentieth, both the question of art's purpose in society and the continuous debate about language and meaning were shaped either in response to or rejection of Wagnerian concepts, whether openly or latently.

Painters were quick to latch on to these debates and to the possibilities they suggested to the creators of so representational an art-form as painting and engraving. Painting as taught at art schools all over Europe had rendered the medium itself invisible in the service of painterly perfection. The wellknown portraits by Franz Xavier Winterhalter and Jean-Auguste-Dominique Ingres offer a good example of this academic approach to visual representation that had become normative by the middle of the century. But with the advent of photography as a mechanical rival to this form of painting, the medium and meaning of painting as the art so highly placed in the canon of artistic disciplines since the Renaissance - when painting and poetry were famously related in the claim that the visual in art should be expressive in a similar manner to the verbal (ut pictura poesis) - took on an urgent need of aesthetic justification. While already a point of discussion in the Romantic aesthetics of an Eugène Delacroix, Caspar David Friedrich, or William Turner, the self-conscious exploration of the painterly medium to convey emotion and significance that lay below the surface of the represented object received a new, avant-garde validation in the guise of Wagnerian aesthetics.

Just as the physical constituents of language were foregrounded by poets, the painterly elements of line, color, and form were explored as visible means of expression in themselves. Painters such as Pierre Bonnard, Paul Cézanne, and Paul Gauguin relied on Wagnerian ideas of leitmotif and tone-color when working toward an equivalent to rhythmic structure and musical organization in their use of specific colors and lines throughout the painting. ${ }^{31}$ The tendency to outline an object - instead of aiming for a representation so perfect that it no longer seemed painted but real - became a means of alienation from the simple object character of the representation in order to create a more abstract composition of color, line, and form. This emotive and synesthesic use of painterly materiality found its full potential in the abstract compositions and experiments of, for example, the artists 
associated with the groups Der blaue Reiter and Die Brücke, and especially with works that themselves carried explicitly musical titles, such as Kandinsky's Improvisations of the 1910s, or Franz Marc's Sonatine for violin and piano (1913). ${ }^{32}$ The well-known association of musicians with these circles (for example, Schoenberg with Der blaue Reiter or Mahler with the Vienna Secession) acted as a source of mutual influence, pushing a Wagnerist agenda well into the fields of modernism.

While on the one hand a new emphasis on the materiality of painting evolved as one aspect of visual Wagnerism, an issue more commonly associated with Wagnerian aesthetics is that of representation versus transcendence. In order to escape the realism and perceived banality of journalistic etchings and photographs that were too close to everyday life, painters tried to grasp in the grand subjects they associated with Wagner the deeper truths of the soul. The inclusion of symbolic objects, colors, and subjects - for example in Moreau's Salome paintings - reinterpreted a centuries-old tradition of painterly symbolism (found, for example, in Renaissance depictions of the Virgin and Child) within a rejuvenated vocabulary of Wagnerism. Furthermore, as in Wagnerian music drama, the subjects themselves were often influenced by the German composer. Some painters (Henri Fantin-Latour, for example) were famous for their renderings of scenes from Wagner's operas, while others - in particular the pre-Raphaelites, such as Edward Burne-Jones with his Percival cycle - found inspiration in Wagner's operas for their own explorations of medieval legends.

These trends were similarly influential in other art forms. Novels like Thomas Mann's Buddenbrooks, Leon Tolstoy's War and Peace, and Marcel Proust's À la recherche du temps perdu present self-conscious literary equivalents to Wagner's Ring des Nibelungen in constructing a complete, self-contained artistic world. D'Annunzio's Decadent novel Il trionfo della morte (1894) is but one literary reworking of the world of Tristan, full of references to the opera and to Wagner's own person and biography, and culminating in a forced love-death.

Yet it was in the context of the theater that the ideas of Wagner became most pervasive. As a dedicated space of theatrical cult based on Wagner's theories of the Gesamtkunstwerk and its staging, Bayreuth provided a model that galvanized producers and directors in all branches of theater. Influenced by Friedrich Nietzsche's reflections on the Wagnerian revival and ancient Greek drama in The Birth of Tragedy (1871) and by graphic artist and architect Peter Behrens, who hailed the modern theater as "celebrations of life" (Feste des Lebens), reformers such as Adolphe Appia and Edward Gordon Craig searched for a new, expressive drama that replaced Victorian realism with Symbolist and abstract stages that left behind the fait divers 
character to direct audiences' perception onto the deeper messages of the piece represented onstage. ${ }^{33}$ One of Wagner's central notions - removing the separation of stage and audience - influenced in particular architects such as Erich Mendelsohn, Bruno Taut, and Henry van de Velde who dreamed of theaters that would break the traditional, box-like structure with its proscenium-framed stages by incorporating the structure of antique arenas or the spatial interaction of Japanese theater. ${ }^{34} \mathrm{~A}$ key building in this movement was the Große Schauspielhaus in Berlin by the young architect Hans Poelzig, who redesigned the former Zirkus Schumann in 1919 as a monumental arena theater for the director Max Reinhardt. Greek tragedy, Shakespeare, and avant-garde were presented in a new "theater for the people" that had its ideological roots in Wagner's theories of a nonbourgeois and non-capitalist theater developed in his post-revolutionary Zurich writings of 1849-51 and further mediated through Nietzsche and others. Theatrical festivals, theoretically for the masses, were legitimized through these Wagnerian dramatic theories and the model of Bayreuth, either in antique arenas such as Béziers and later Verona, or in newly constructed buildings, like those of the Salzburg festival.

Indeed, during the high point of European Wagnerism across the turn of the nineteenth and twentieth centuries, musical Wagner reception and artistic Wagnerism could come together in theatrical festivals of this kind, as for instance when Déodat de Séverac's open-air spectacle Héliogabale was performed in the arena of Béziers, in Provence, before 15,000 spectators as an occasion to "educate the masses" through the "noble teachings of history and legend." 35 In this case, the Wagnerian claim to reviving Greek theater was countered with a nationalist French music drama, performed in a space whose link to antiquity was far more tangible than that of Bayreuth could ever claim. How strongly these French festivals of the fin de siecle were indebted to Wagnerian rhetoric is obvious from an earlier performance, which took place in the Orange amphitheater in 1894. Saint-Saëns, in the role of Wagnerian "musician-poet," wrote an Hymne à Pallas Athénée performed here by Lucienne Bréval. The singer, dressed in Greek costume, "sang the magnificent Greek liturgy under a large fig tree ... and with the sky forming the only ceiling of the theater, the beautiful pagan prayer rose freely to the caressing stars. ${ }^{\text {"36 }}$ Saint-Saëns's hymn celebrated the rebirth of Greek drama, culture, and politics in its new Mediterranean successor (France), and thereby presented a barely disguised challenge to the German composer - once his hero, but by now an aesthetic and musical opponent.

By the turn of the twentieth century, Wagner had become a key figure in European culture, and by its middle his ideas had so permeated artistic and aesthetic discourses that their acceptance (or rejection) was less a statement of Wagnerism than the upholding or denying of presumed 
universal truths. As a writer who forged a theoretical system that placed art at the center of existence, in a position previously occupied by religion (or, in the case of G. W. F. Hegel, philosophy), Wagner had shifted the role of art from its traditional marginality in terms of politics, history, and economics. To this theoretical paradigm shift, Wagner's music added a seductive sound-world that swept away audiences and fellow musicians across Europe, challenging composers and inspiring painters, sculptors, and poets. But his theoretical and musical offerings contained a darker side that would become more and more obvious in the twentieth century. In the world of Realpolitik, the Wagnerian systems of a total work of art (Gesamtkunstwerk) translated easily into all-encompassing political totalitarianism, in which Hitler's "empire of a thousand years" could become a demagogue's artwork of the future. While this late and abusive stage of ideological Wagnerism delivered a belated coup de grâce to the phenomenon, musical and aesthetic responses to Wagner still continue: the opening example of Shore's score for The Lord of the Rings will obviously not be the last. 


\section{University Library}

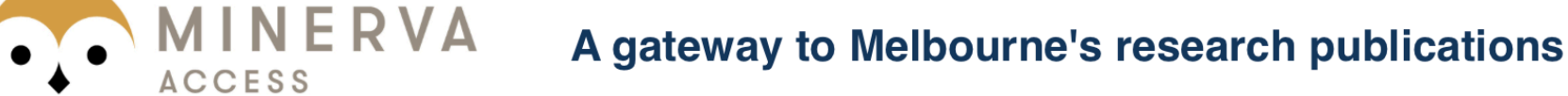

Minerva Access is the Institutional Repository of The University of Melbourne

Author/s:

FAUSER, A

Title:

Wagnerism: Responses to Wagner in Music and the Arts

Date:

2008

Citation:

FAUSER, A. (2008). Wagnerism: Responses to Wagner in Music and the Arts. Grey, T (Ed.). The Cambridge Companion to Wagner, (1), pp.221-234. Cambridge University Press.

Persistent Link:

http://hdl.handle.net/11343/28086 